\title{
Epicuticular wax in honey mesquite: Seasonal accumula- tion and intraspecific variation
}

\author{
P.W. JACOBY, R.J. ANSLEY, C.H. MEADORS, AND A.H. HUFFMAN
}

\section{Abstract}

Epicuticular wax on the leaves of honey mesquite (Prosopis glandulosa) increased rapidly from May to July and stabilized or decreased by late summer. Pattern of accumulation best fit a second order polynomial regression equation using day of year as the independent variable. Considerable variation in wax accumulation was found among individual trees within populations and appeared to be consistent from year to year. Wax generally increased from about $0.35 \mathrm{~g} \mathrm{~m}^{-2}$ to more than $1.00 \mathrm{~g} \mathrm{~m}^{-2}$ during the growing season. A difference in maximum wax accumulation was detected between the 2 years of study and was attributed to differing environmental conditions. These findings may partially explain resistance of honey mesquite to foliar-applied herbicides.

Key Words: Prosopis glandulosa, physiology, resistance, brush control, stress

Wax and cutin are primary components of the leaf cuticle, a noncellular membrane covering the leaf epidermal cells (Martin 1960). Waxes consist mainly of long-chain paraffins, alcohols, ketones, esters, and free fatty acids in proportions determined by both genetic capability and environmental factors (Silva Fernandez et al. 1964, Hull et al. 1979, Wilkerson 1980). Epicuticular wax increases leaf reflectance of visible and near infrared radiation, thus reducing net radiation and cuticular transpiration and possibly contributing to drought resistance of plants (Kurtz 1950, Ebercon et al. 1977, Hull and Bleckmann 1977). These waxes are also associated with resistance of plants to absorption and penetration of foliar-applied herbicides (Hammerton 1967, Sharma and Vanden Born 1970, Wilkinson 1980).

Leaves of mesquite (Prosopis spp.) are capable of developing a thick waxy cuticle (Hull 1970, Meyer et al. 1971). Kurtz (1950) found wax on velvet mesquite ( $P$. velutina) to increase with leaf maturity, while Mayeux and Jordon (1984) associated most rapid wax accumulation on honey mesquite $(P$. glandulosa) with early leaf development and expansion. The latter authors surveyed wax amounts on mesquite from several locations across Texas, finding significant variation among populations but little variation within a population.

The objective of this study was to describe seasonal accumulation of honey mesquite leaf wax in the Rolling Plains resource area of Texas. A secondary objective to examine intraspecific variation was included after preliminary data revealed significant variation occurred among individual trees selected for the seasonal accumulation study. Both objectives support a larger effort to identify and quantify sources of resistance in honey mesquite to foliar-applied herbicides.

\footnotetext{
Authors are professor, postdoctoral research associate, and research associate, Texas Agricultural Experiment Station, P.O. Box 1658, Vernon 76384; and range conservationist, Soil Conservation Service, USDA, Brackettville, Texas, respectively. At the time of the research, junior author was a research technican with TAES.

Published with the approval of the director, Texas Agricultural Experiment Station as TA-24941. Research was funded in part by University Lands-Surface Leasing Interests, Univ. Texas System, Midland; E. Paul and Helen Buck Waggoner Foundation, Vernon, and Brush Control and Range Improvement Association, Albany.

Authors wish to acknowledge $\mathbf{R h o n d a}$ Woolf for assistance in laboratory analysis. Manuscript accepted 21 December 1989.
}

\section{Materials and Methods}

Five honey mesquite trees located on a clay loam range site (Typic Paleustoll) near Dickens in northwestern Texas were sampled biweekly during the summers of 1980 and 1983 . Additionally, 5 trees were sampled biweekly from a clay loam site (Pachic Argiustoll) near Vernon, Texas, in 1983. A sample consisted of approximately 20 leaves from the center of each tree canopy. Following removal, leaves were placed in a cooler during transport from the field and stored frozen until analysis.

Prior to wax removal, leaves were thawed and leaflets were individually separated from the rachis to compile a sub-sample having an approximate surface area of $100 \mathrm{~cm}^{2}$ as determined by a leaf area meter ${ }^{1}$. Sub-samples were gently rinsed in distilled water to remove foreign material, air dried, and placed in a 250 -ml beaker to which $40 \mathrm{ml}$ of analytical grade chloroform ( $99 \%$ pure) heated to $45^{\circ} \mathrm{C}$ was added. After $30 \mathrm{~s}$ the chloroform was poured into preweighed foil pans which were then placed in a vented hood and evaporated to dryness for 24 hours. Foil pans were then reweighed to quantify the amount of residual wax. Amount of wax for a field sample was the mean of 4 laboratory replications. Wax was reported on a weight per area basis $\left(\mathrm{g} \mathrm{m}^{-2}\right)$ derived by dividing wax weight by the actual area of the sub-sample unit.

Data were subjected to analysis of variance and individual plant means were separated according to Duncan's multiple range test (Steel and Torrie 1980). Statistical comparisons, using laboratory replicates were made among trees within sampling dates, while means of trees were used to compare wax loads among sampling dates. Regression analyses were used to estimate seasonal wax accumulation.

Intraspecific variation in wax amounts was estimated by sampling 4 mesquite populations on widely separated locations during 1983. Twenty trees from each population located near Guthrie, Post, Dumas, and Ozona, Texas, were sampled in the same manner as previously described. Dates of collection and descriptions of these sites are shown in Table 1.

ILI-COR- LI-3000, Lambda Instruments, Lincoln, Nebr. 68504.

Table 1. Descriptions of sites where epicuticular wax samples were taken from honey mesquite populations.

\begin{tabular}{llcl}
\hline \hline $\begin{array}{l}\text { Ecological } \\
\text { Region }\end{array}$ & $\begin{array}{c}\text { Collectin } \\
\text { Location }\end{array}$ & Date & $\begin{array}{c}\text { Soil } \\
\text { Classification }\end{array}$ \\
\hline Rolling Plains & Dickens & $\begin{array}{c}1980 \text { and 1983 } \\
\text { (biweekly) } \\
1983\end{array}$ & Aridic Paleustoll \\
Rolling Plains & Vernon & $\begin{array}{c}\text { Pachic Argiustoll } \\
\text { (biweekly) }\end{array}$ & $\begin{array}{c}\text { Aridic Paleustoll } \\
\text { Typic Paleustoll }\end{array}$ \\
$\begin{array}{l}\text { South Plains } \\
\text { Rolling Plains } \\
\text { Edwards Plateau Ozona }\end{array}$ & $\begin{array}{l}\text { Post } \\
\text { Guthrie }\end{array}$ & $\begin{array}{c}\text { 15 June 1983 } \\
\text { Petrocalcic } \\
\text { Calciustoll }\end{array}$ \\
High Plains & Dumas & 7 July 1983 & $\begin{array}{c}\text { Calciorthidic } \\
\text { Paleustoll }\end{array}$ \\
\hline
\end{tabular}



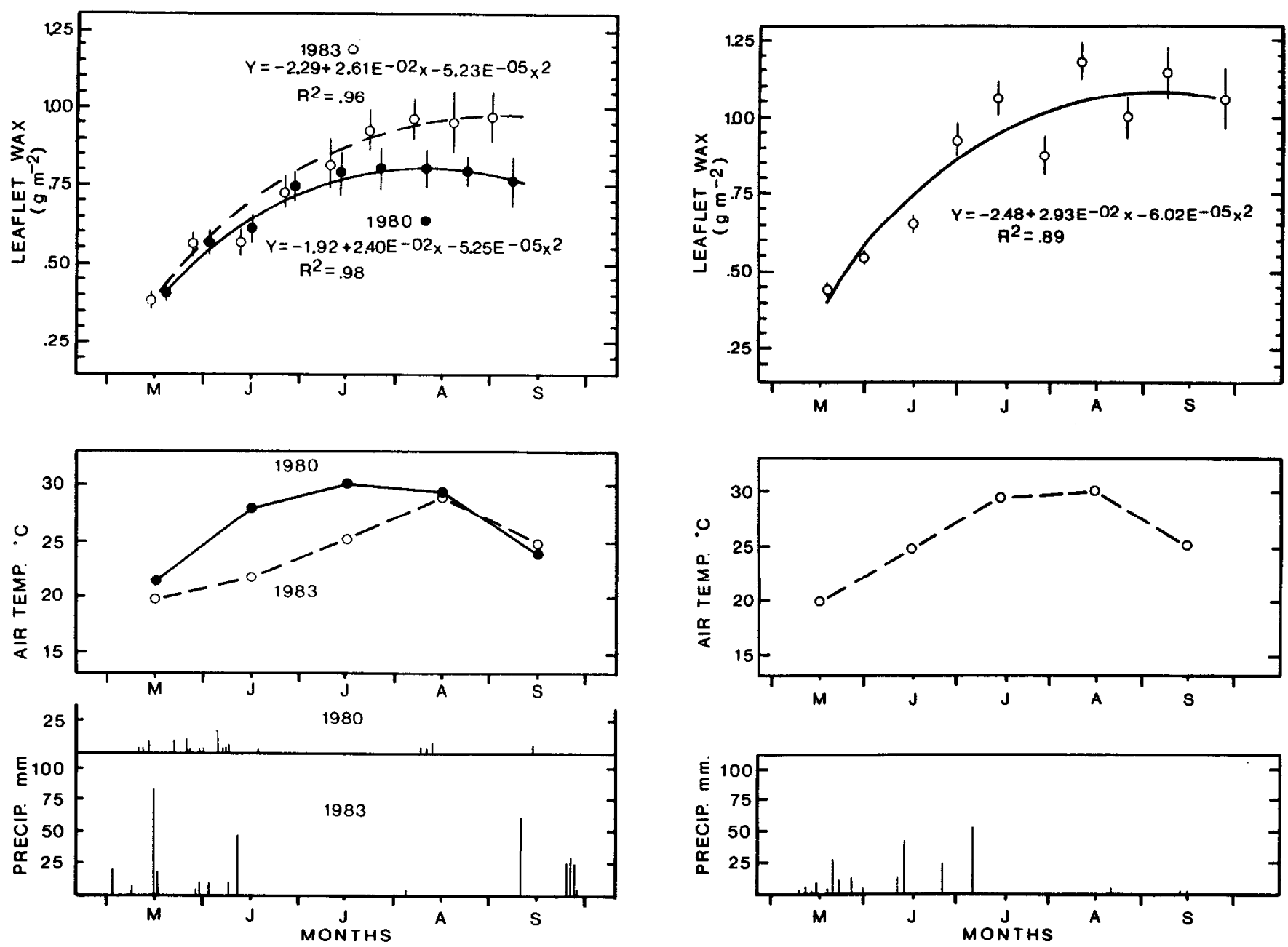

Fig. 1. Seasonal accumulations of epicuticular wax on leaves of 5 honey mesquite trees near Dickens, Texas, during 1980 and 1983. Date points are means and 1 SE. Mean monthly air temperature during the growing season and daily precipitation are shown on equal time seales to wax accumulation. Dependent variable (Y) is epicuticular wax in $g \mathrm{~m}^{-2}$ as related to date expressed as day $(0-360)$ of year $(X)$.

\section{Results and Discussion}

\section{Seasonal Accumulation of Wax}

Epicuticular wax on the leaves of honey mesquite accumulated rapidly from May through July on rangeland near Dickens in northcentral Texas during 2 years of study (Fig. 1). A similar trend was seen in a higher rainfall area $200 \mathrm{~km}$ east near Vernon during 1983 (Fig. 2). Wax accumulation stabilized or ceased by late July and some loss was apparent near the end of the growing season. These findings concur generally with those of Mayeux and Jordan (1984), who found little increase in wax on honey mesquite leaves after July at most of 6 locations sampled in Texas during 1981. Pattern of seasonal wax accumulation best fit second-order polynomial regression equations in which the dependent variable, wax load, was predicted by the independent variable, time, as expressed as day of year.

While seasonal patterns were similar during both years of study, we found mean wax accumulation to be less in 1980 when drought conditions prevailed than during 1983 , which resembled a normal year climatically (Fig. 1). Despite more rainfall during May and early June in 1983, wax accumulation closely paralleled that of the drier 1980 through mid July. In 1983 , wax continued to accumulate through early August as opposed to 1980 when wax accumulation

Fig. 2. Seasonal accumulation of epicuticular wax near Vernon, Texas during 1983 from 5 honey mesquite trees. Mean monthly air temperature and daily precipitation are shown on the same time scale as wax accumulation. Dependent variable (Y) is epicuticular wax in $\mathrm{g} \mathrm{m}^{-2}$ as related to date expressed as day $(0-360)$ of year $(X)$.

stablized in mid July. Despite some unexplained reductions in wax load at the Vernon site, the general pattern showed wax accumulated through mid August as shown at the Dickens site in the same year. These data agree with the findings of Mayeux and Jordan (1984), who found a similar seasonal trend at Vernon in 1981.

While the differences in overall wax load between 1980 and 1983 for the honey mesquite plants at Dickens remain unexplained, we hypothesize that they relate to extreme differences in growth conditions between the 2 years. The combination of low rainfall in late spring with higher than normal temperatures during summer undoubtedly placed restraints on plant activity during 1980 . This hypothesis would link wax production with climatic variables and would appear to differ with the conclusions of Mayeux and Jordan (1984), who found similar levels of wax on honey mesquite growing in arid and mesic environments of Texas during 1981. Our findings also differ with trends found in alfalfa where increasing levels of epicuticular wax were correlated with decreasing levels of irrigation (Jefferson et al. 1989).

While both rainfall and temperature are major driving variables for plant growth, temperature appears to be more closely related to the pattern of wax accumulation in honey mesquite. The ability of the extensive root system of mesquite to obtain moisture from great distances may account for the limited association of rainfall 

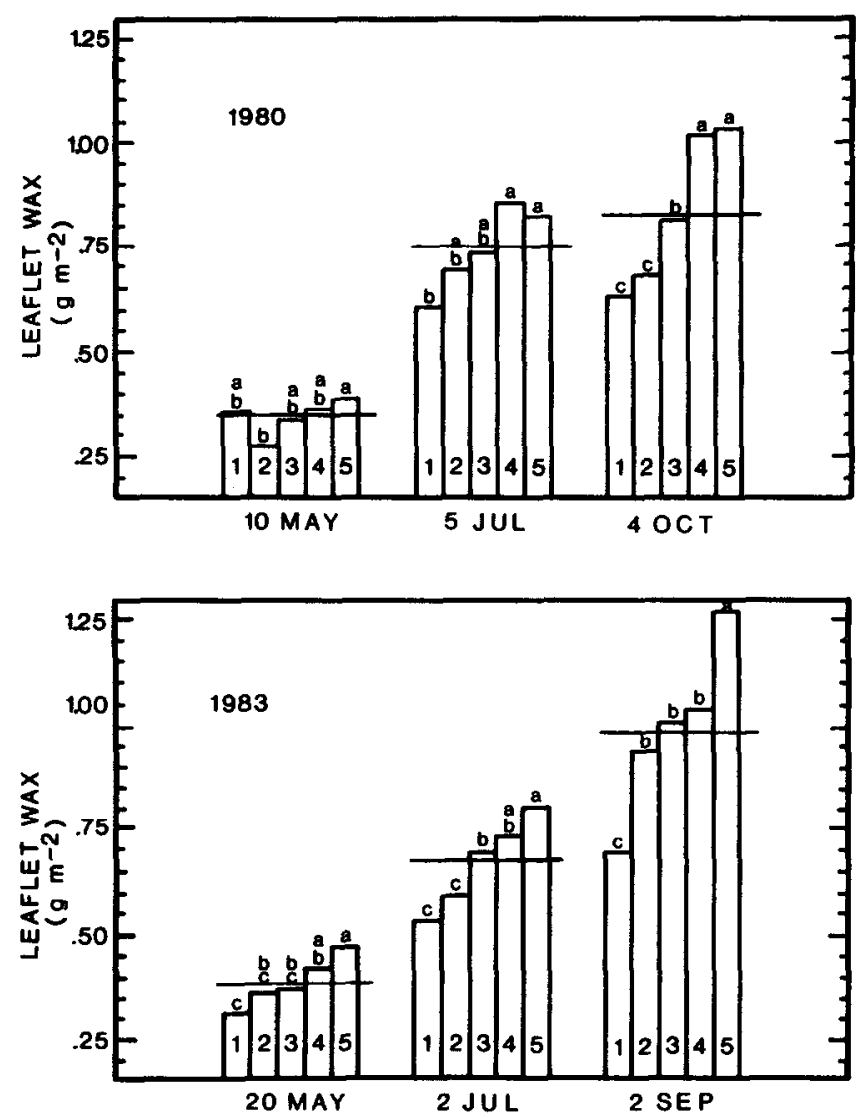

Fig. 3. Wax loads from 5 individual honey mesquite trees (1-5) near Dickens, Texas, at 3 dates during the growing season in 1980 and 1983. Horizontal line represents the population mean. Within a date any column (tree) not superscripted with the same letter is significantly $(P>0.05)$ different from the others.

events with wax accumulation (Fig. 1-2). Precipitation during the summer months is typically low in the study region which follows a bimodal pattern during spring and fall. Temperatures, however, were extremely different during the 2 years, exceeding $35^{\circ} \mathrm{C}$ by early June in 1980 and not reaching that level until mid-August during 1983. Growth of honey mesquite may be retarded when temperatures exceed $35^{\circ}$ (Scifres and Brock 1972, Hanson 1982), and this suggests growth was restricted more severely during 1980 than in 1983. If wax production is regulated to some extent by overall plant activity during the growing season, lower accumulation of wax in 1980 than in 1983 may be attributed to less than optimal growing conditions.

\section{Intraspecific Variation in Wax Accumulation}

Comparison of wax accumulation among the 5 individual trees sampled near Dickens during 1980 revealed significant differences, particularly after mid-summer (Fig. 3). Specific trees were consistently higher in wax load than others across all sampling periods. When the same trees were sampled in 1983, similar differences among the wax loads were observed. Trees which were high wax accumulators in 1980 remained consistent in their ability to accumulate high wax loads in 1983, suggesting that wax amounts are genetically controlled. Similarities in tree size and structure and proximity of individuals on a site seemed to rule out site or physical differences as explanations for the variation. Differences were also seen among the trees included in the seasonal sampling near Vernon in 1983, suggesting this intraspecific variation is common.

Additional support for establishing the existence of intraspecific variation in wax accumulation among honey mesquite was gained by sampling 20 trees at several locations during 1983. Because the sites were widely distributed across western Texas, repeated sampling of the sites was not attempted. Mean wax load for trees at these sites was compared to that predicted on those dates using the regression equations for Dickens and Vernon, and, with the exception of the Ozona site, was within the $95 \%$ confidence limits predicted by the Dickens equations (Table 2). Data from Post, Guthrie, and Dumas probably agreed closely with the Dickens model

Table 2. Ranges and means of epicuticular wax from $\mathbf{2 0}$ mesquite trees at each of 4 locations in western Texas on single dates of collection in 1983.

\begin{tabular}{|c|c|c|c|c|c|}
\hline \multirow[b]{2}{*}{ Location } & \multicolumn{2}{|c|}{-DDate-_- } & \multicolumn{2}{|c|}{ - Leaf Wax- } & \multirow[b]{2}{*}{$\bar{x} \pm \mathrm{SE}$} \\
\hline & Calendar & $\begin{array}{c}\text { Day of } \\
\text { Year }\end{array}$ & High & Low & \\
\hline & \multicolumn{5}{|c|}{$\cdots-\mathrm{g} \mathrm{m}^{-2} \cdots$} \\
\hline Post & 25 May & 145 & 0.68 & 0.38 & $0.54 \pm 0.013$ \\
\hline Guthrie & 7 June & 158 & 0.76 & 0.44 & $0.61 \pm 0.015$ \\
\hline Ozona & 15 June & 165 & 0.89 & 0.65 & $0.80 \pm 0.019$ \\
\hline Dumas & 7 July & 188 & 0.96 & 0.61 & $0.75 \pm 0.026$ \\
\hline
\end{tabular}

because of geographic proximity and similarity of soils. Ozona is the farthest site from Dickens and several hundred kilometers to the south. Leaves at Ozona were at least 2 weeks older than those at the other sites to the north, and this advanced development probably explains why the model developed to the north and based on day of year failed to accurately predict the wax load for that population. Comparison of the intraspecific variation observed at each site concurs with trends seen in the seasonal studies near Dickens and Vernon, illustrating that variation within a population becomes progressively greater as some trees exhibit an ability to accumulate greater wax loads than others within the same population.

\section{Management Implications}

Increasing amounts of epicuticular wax on the leaves of honey mesquite during early summer may contribute to increasing resistance to foliar-applied herbicides. Herbicide applications made towards mid summer should probably contain additional adjuvants to aid in the absorption and penetration of herbicide through this waxy barrier. The variation in wax loads among trees within populations may partially explain why some trees survive herbicide applications and may contribute to herbicide resistance in subsequent populations of honey mesquite.

\section{Literature Cited}

Ebercon, A., A. Blum, and W.R. Jordan. 1977. A rapid colorimetric method for epicuticular wax content of sorghum leaves. Crop Sci. 17:179-180.

Hammerton, J.L. 1967. Environmental factors and susceptibility to herbicides. Weeds 15:330-336.

Hanson, J.D. 1982. Effect of light, temperature and water stress on net photosynthesis in two populations of honey mesquite. J. Range Manage. 35:455-458.

Hull, H.M. 1970. Leaf structure as related to absorption of pesticides and other compounds. Residue Rev. 31:1-155.

Hull, H.M., and C.A. Bleckmann. 1977. An unusual epicuticular wax ultrastructure on leaves of Prosopis tamarugo. Amer. J. Bot. 64:1083-1091.

Hull, H.M., F.W. Went, and C.A. Bleckmann. 1979. Environmental modification of epicuticular wax structure of Prosopis leaves. J. ArizonaNevada Acad. Sci. 14:39-42.

Jefferson, P.G., D.A. Johnson, M.D. Rumbaugh, and K.H. Asay. 1989. Water stress and genotypic effects on epicuticular wax production of alfalfa and crested wheatgrass in relation to yield and excised leaf water loss rate. Can. J. Plant Sci. 69:481-490.

Kurtz, E.B., Jr. 1950. The relation of the characteristics and yield of wax to plant age. Plant Physiology 25:269-278. 
Martin, J.T. 1960. Determination of the components of plant cuticles. J. Sci. Food Agr. 11:635-640.

Mayeux, H.S., Jr., and W.R. Jordan. 1984. Variation in amounts of epicuticular wax on leaves of Prosopis glandulosa. Bot. Gaz. 145:26-32.

Meyer, R.E., H.L. Morton, R.H. Haas, E.D. Robison, and T.E. Riley. 1971. Morphology and anatomy of honey mesquite. U.S. Dep. Agr. Tech. Bull. 1423. 186 p.

Scifres, C.J., and J.H. Brock. 1972. Emergence of honey mesquite seedlings relative to planting depth and soil temperature. J. Range Manage. 25:217-219.
Sharma, M.P., and W.H. Vanden Born. 1970. Foliar penetration of picloram and 2,4-D in aspen and balsam poplar. Weed Sci. 18:57-63.

Silva Fernandez, A.M., E.A. Baker, and J.T. Martin. 1964. Studies on plant cuticle-VI. The isolation and fractionation of cuticular waxes. Ann. Appl. Biol. 53:43-58.

Steel, R.G.D., and J.H. Torrie. 1980. Principles and procedures of statistics-A biometric approach. McGraw-Hill Book Co. New York.

Wilkerson, R.E. 1980. Ecotypic variation of Tamarix pentandra epicuticular wax and possible relationship with herbicide sensitivity. Weed Sci. 28:110-113. 